\title{
MAKNA BALAGANJUR DALAM AKTIVITAS SOSIAL MASYARAKAT BALI
}

\author{
I Wayan Suharta \\ Jurusan Pedalangan, Fakultas Seni Pertunjukan, \\ Institut Seni Indonesia Denpasar, Indonesia
}

\begin{abstract}
Balaganjur is a form of performance arts and audiovisually it might be an independent art. Balaganjur is a musical communication that instigates sensation and emotional response between the composer, players and viewers. It might influence the fan who are familier with the background of Balinese social life. This article is meant to see and analyze how Balinese people value the function of Balaganjur, especially in the context of festive social activity. The performance of Balaganjur is always conected to a religious life, traditional lore, and aspect of artistic life in response to the development of the cultural millie. Generally, Balaganjur complements the implementation of religious ritual. However, when Balaganjur is secularly composed and performed as an aesthetic presentation, Balaganjur develops its function toward profan values.
\end{abstract}

Keywords: Balaganjur, religius and profan

Balaganjur adalah sebuah orkestra tradisional Bali yang memiliki perangai keras, didominasi oleh alat-alat perkusi dalam bentuk lepas. Ciri yang sangat menonjol untuk menentukan identitas Balaganjur bahwa umumnya dimainkan sambil berjalan kaki untuk mengiringi kegiatan-kegiatan tertentu yang sifatnya prosesi. Balaganjur terbentuk dari berbagai jenis alat dengan "warna" suara yang beraneka ragam. Kendati demikian, semua jenis alat tersebut masih memiliki kesamaan dari cara memainkannya yaitu dengan cara dipukul (Sugiartha, 1996:31).

Secara fisik Balaganjur didominasi oleh instrumen-instrumen berpencon, bentuk instrumen-instrumen tersebut pada dasarnya sama, hanya saja terdapat perbedaan ukuran besar-kecil setiap bagian instrumen. Alat-alat yang menjadi kesatuan barungan Balaganjur dapat dikelompokkan menjadi kelompok instrumen pemegang melodi, kelompok instrumen pemberi ornamentasi, kelompok instrumen pemurba irama dan kelompok instrumen pengatur matra. 
Kelompok instrumen pemegang melodi, dimainkan oleh enam orang penabuh (pemain gamelan); empat orang pemain reyong dan dua orang sebagai pemain ponggang. Instrumen pemberi ornamentasi yaitu cengceng kopyak, pemainnya tidak tetap antara enam sampai duabelas orang. Kelompok instrumen pemurba irama yaitu dua buah kendang (lanangwadon) dimainkan oleh dua orang. Instrumen pengatur matra; meliputi dua buah gong (lanang-wadon) dimainkan oleh seorang penabuh, sebuah tawatawa, sebuah kempli, sebuah kempul dan sebuah bende yang masing-masing dimainkan oleh seorang penabuh. Karena Balaganjur adalah musik prosesi, maka diperlukan tenaga tambahan yang membantu membawakan gong empat orang, kempul satu orang dan bende satu orang. Jadi secara keseluruhan penabuh yang diperlukan untuk mendukung penyajian Balaganjur antara 25 sampai 35 orang.

Balaganjur merupakan salah satu wujud kesenian yang hingga sekarang masih mencerminkan karya seni yang adiluhung, sehingga harus dilestarikan keberadaannya. Namun demikian kedudukan Balaganjur akhirakhir ini telah menghadapi masalah yang dapat dikatakan dilematis, meskipun tidak secara keseluruhan meng-anggap demikian. Pada satu pihak merisaukan bahwa Balaganjur tengah terancam nilai-nilai keasliannya, disisi lain justru keberadan Balaganjur semakin kokoh, kendatipun ditengahtengah gelombang modernisasi yang begitu pesat.

Sebagai seni tradisional kesadaran untuk mengembangkan Balaganjur di kalangan seniman dan masyarakat Bali semakin bergaerah. Perhatian yang sungguh-sungguh dalam menggarap seni karawitan ini begitu menonjol bila dibandingkan dengan jenis karawitan yang lain. Walaupun gamelan merupakan bagian tak terpisahkan dari seni pertunjukan, secara audio-visual Balaganjur dapat berdiri sebagai seni tersendiri. Maka kemudian yang harus dipikirkan adalah bagaimana upaya yang dilakukan agar Balaganjur tetap lestari, akan tetapi juga harus mendasarkan pada sikap terbuka terhadap kemungkinan penyesuaian unsur-unsur seni yang ada, sehingga relevan dan diterima menurut situasi zamannya.

Tulisan ini akan mengkaji eksistensi Balaganjur dewasa ini dengan berbagai inovasinya, terutama mengenai makna Balaganjur ketika Balaganjur sedang mengalami proses sekularisasi dengan dampak membawa "perubahan estetis" secara musikalitas. Perubahan yang dimaksud lebih mengarah kepada pengembangan khasanah yang dimiliki Balaganjur, yang pada intinya lebih banyak berpijak pada konsep dasar yang telah ada untuk menghasilkan karya-karya yang inovatif, mantap dan masih mampu dicerna oleh masyarakat pendukungnya.

Dengan menjadikan Balaganjur sebagai topik tulisan ini, penulis bermaksud untuk menyajikan bagaimana masyarakat di Bali memberikan makna terhadap penyajian Balaganjur terutama dalam konteks aktivitas sosial masyarakat, baik yang berkaitan dengan aspek kehidupan beragama 
dan adat, maupun dengan aspek kehidupan berkesenian dalam menghadapi perubahan di lingkungan budayanya. Beberapa hal penting yang menjadi catatan bahwa 1) Balaganjur masih tetap eksis dan unsur-unsurnya telah banyak mengalami perkembangan; 2) Balaganjur telah memiliki satu konsep garap yang mapan untuk melahirkan karya-karya yang baru; dan 3) dewasa ini telah lahir kreasi-kreasi Balaganjur, baik hasil karya para seniman muda maupun seniman tua dengan mengadopsi unsur-unsur seni kekinian yang dapat memperkaya khasanah Balaganjur itu sendiri.

Kesenian seperti Balaganjur adalah salah satu unsur kebudayaan memiliki wujud dan peran yang sangat menonjol dalam mengisi tujuan, yang berorientasi kepada pelestarian nilai-nilai budaya. Sebagai bagian dari kebudayaan kesenian merupakan simbol dari masyarakat dan mengandung nilai-nilai yang hidup di dalam masyarakat. Tema-tema yang diangkat sebagai isi dari kesenian itu pada dasarnya bersumber dari kehidupan masyarakat.

Hakekat hidup orang Bali yang berpedoman pada hukum karma phala, sikap hidup yang berorientasi pada dualisme; baik dan buruk, sangat berpengaruh terhadap kesenian Bali (Bandem, 1996:33). Tema-tema kesenian Bali sebagian besar berangkat dari dualisme tersebut sehingga muncul norma dan etika yang kuat serta mengandung makna tertentu bagi setiap pertunjukan kesenian. Makna penyajian seperti Balaganjur sangat bergantung pada fungsinya. Ketika Balaganjur berfungsi melengkapi pelaksanaan ritual keagamaan Balaganjur memiliki makna religius dan ketika Balaganjur mengalami sekularisasi yang berorientasi seni presentasi estetis, Balaganjur mengalami perkembangan makna yang mengarah kepada makna profan.

\section{BALAGANJUR DALAM MAKNA RELIGIUS}

Kehidupan masyarakat Bali di masa silam sangat tergantung dengan alam. Perilaku mereka mencerminkan pemikiran magis dan sakral yang kuat seperti keyakinan adanya hubungan antara manusia dengan kekuatan gaib, serta relasi antara manusia dengan kekuatan spiritual. Persepsi yang relegius ini menunjukan sudah adanya gejala-gejala tentang kepercayaan kepada kekuatan spiritual tertinggi atau Tuhan, yang dikondisikan oleh alam pikiran mereka memuja kekuatan alam dan alam gaib (Suartaya, 2001:130).

Di kalangan masyarakat Hindu di Bali kesenian persembahan kepada Tuhan dan alam niskala dapat dibedakan menjadi dua kelompok; kesenian wali dan kesenian bebali. Kesenian wali mencakup berbagai bentuk kesenian yang tergolong tua dan oleh karena itu telah memiliki unsur-unsur keaslian (originalitas) dan kesucian. Dikalangan masyarakat Bali seni sakral merupakan salah satu aspek vital kehidupan spiritual masyarakat Hindu yang 
bermakna relegius yang merupakan bagian integral dari pelaksanaan upacara (Dibia, 2003:98).

Balaganjur dalam kaitannya dengan kegiatan ritual merupakan implementasi dari sosio-relegius yang sangat ketat dan kuat memberikan dukungan terhadap keberadaan Balaganjur. Dalam kontek religius, semua angota sekaa terlibat dalam penyajian Balaganjur sesuai dengan tugas dan fungsinya masing-masing, yang semuanya dilandasi dengan perasaan tulus yang disebut ngayah.

Ketika terlibat dalam kegiatan ritual, para penabuh Balaganjur menyerahkan diri secara tulus demi suatu kepercayaan yang mereka yakini. Berpatisipasi megambel terutama bagi kaum pria yang me-rasa mampu, selain untuk mengekpresikan naluri berkesenian namun pada intinya merupakan yadnya bagi kehidupannya dibawah perlindungan dari kekuatan Yang Maha Kuasa.

Yadnya atau pengorbanan suci mencakup penyerahan diri sering kali melibatkan upacara-upacara ritual. Berpegang kepada keyakinan bahwa kesenian adalah ciptaan Tuhan, orang Hindu men-jadikan kesenian sebagai sebuah persembahan dan yadnya untuk mendekatkan diri kepada Tuhan. Dengan yadnya dimaksudkan bahwa berkesenian itu tidak saja memuaskan serta memenuhi dorongan estetis pribadi atau masyarakat, tapi juga sebagai wahana bagi seniman untuk mendekatkan dirinya kepada sumber keindahan itu, yaitu Tuhan.

Eksistensi masyarakat Bali dalam mengekpresikan peng-akuannya terhadap kebesaran Ida Sanghyang Widhi diejawantahkan dalam wujud ngayah tersebut. Budaya ini selalu diaktualisasikan dan diimplementasikan dalam gerak laku masyarakat Bali hingga sekarang. Dalam bidang kesenian misalnya, semua orang merasa memiliki peran. Mereka yang tak bisa menari atau menabuh mungkin bertugas menata atau mengerjakan dekorasi panggung. Termasuk juga ketika membantu para penari mengenakan kostum tarinyapun sudah termasuk ngayah. Begitu juga bila berpartisipasi mengangkat gamelan dan mengurus konsumsi penari dan penabuh juga termasuk ngayah.

Terkait dengan prinsip ritual seniman-seniwati di Bali yang berkesenian atas dasar ngayah, baik kepada masyarakat maupun kepada Tuhan selalu melibatkan unsur-unsur ritual dalam setiap aktivitas berkesenian untuk menjaga kesucian karya seni yang dihasilkan. Selain itu, upacara ritual dilaksanakan sebagai suatu cara untuk memohon lindungan Ida Sanghyang Widhi Wasa dengan segala manifestasinya agar penyajian kesenian dapat berlangsung sebagaimana mestinya dan yang lebih penting lagi bisa memperoleh kekuatan sinar suci-Nya (Ibid., p. 101).

Untuk mengawali penyajian Balaganjur atau jenis pertunjukan yang lain, sudah menjadi kebiasaan bagi para seniman seni pertunjukan di Bali untuk melakukan upacara ritual. Upacara ritual seperti ini akan selalu 
mengingatkan para seniman akan keberadaan Tuhan. Disamping itu, juga memperlihatkan bahwa berkesenian adalah sebuah persembahan yang bermakna relegius yang intinya mengingatkan pelaku seni akan kebesaran Tuhan Yang Maha Esa.

Kehidupan berkesenian bagi masyarakat Bali menjadi satu aspek yang sangat menonjol dalam kehidupan sehari-hari, karena sebagian besar dari wujud hidup keseharian itu dibarengi dengan penyertaan unsur-unsur benda, aktivitas dan pilosofi yang bernilai seni. Terbentuknya kelompok-kelompok kesenian seperti; sekaa gong, sekaa barong, sekaa angklung dan sebagainya, menunjuk pada aspek kesenian yang dapat berorientasi ekonomi. Sekaasekaa tersebut menunjukkan kelompok kesenian yang memiliki makna relegius dan banyak dihubungkan dengan ketakso; kreativitas budaya yang memberikan kekuatan spiritual untuk mewujudkan keseniannya. Karena itu peranannya dalam menunjang kegiatan adat dan agama khususnya upacara menjadi sangat besar (Astika, 1994:121).

Balaganjur dalam fungsinya mengiringi prosesi ritual keagamaan memiliki makna relegius. Penabuh Balaganjur oleh puluhan partisipan mengikuti ritual dalam prosesi ritual keagamaan. Kendatipun para penabuh tidak disakralkan akan tetapi saat keterlibatan mereka ketika ngayah, baik sebelum memulai atau seusai menyajikan gending-gending Balaganjur, para penabuh mendapatkan percikan air suci, mendapatkan berkah atau pembersihan diri secara niskala.

\section{Makna Keseimbangan}

Gending-gending yang dirangkai secara permanen dengan pelaksanaan suatu upacara yadnya sedikit banyak dapat memperlancar jalannya upacara. Keterpaduan antara gending dengan pelaksanaan upacara dapat bermanfaat untuk menjaga keseimbangan hidup masyarakat dan mencerminkan pola kehidup-an yang fleksibel. Balaganjur dengan gendinggending yang disaji-kan menyimpan nilai-nilai kehidupan yang sangat luhur dan bermanfaat besar terhadap pola kehidupan sebagai mahluk sosial.

Dalam konteks yang lebih luas, kehadiran Balaganjur sering menjadi kebutuhan yang sangat penting. Suatu pelaksanaan upacara tertentu dirasakan kurang mantap tanpa kehadiran suara Balaganjur yang dilengkapi dengan kidung-kidung ritual sehingga kemeriahan suasana menjadi lebih mantap. Keterikatan antara Balaganjur dengan ritual keagamaan akan melahirkan perilaku-perilaku sosial yang kemudian mengarah kepada pembentukan nilai-nilai budaya sehingga dapat dijadikan pedoman bagi warga masyarakatnya. Bala-ganjur dipandang sangat penting karena dapat memenuhi kebutuhan warga masyarakat secara moral dan spiritual. Gending-gending yang disajikan untuk kebutuhan upacara adalah untuk menjaga ke-seimbangan sekaligus meningkatkan kualitas hidup masyarakat. 
Keseimbangan yang mencakup persamaan dan perbedaan dapat terefleksi dalam beberapa dimensi. Refleksi keseimbangan yang banyak ditemukan dalam kesenian Bali adalah dimensi dua dan tiga. Dengan konsep keseimbangan ini dapat dilihat bagaimana penganut agama Hindu menggunakan nilai-nilai estetis untuk menciptakan dan mencapai kehidupan yang damai (Dibia, op. cit. p.100).

Konsep keseimbangan yang berdimensi dua dapat menghasilkan bentuk-bentuk simetris yang sekaligus asimetris atau jalinan yang harmonis sekaligus disharmonis yang lazim disebut dengan rwa bhineda. Dalam konsep rwa bhineda terkandung pula semangat kebersamaan, adanya saling keterkaitan dan kompetisi mewujudkan interaksi dan persaingan. Keseimbangan dalam dimensi dua menjadi salah satu konsep dasar dalam musik Bali termasuk Balaganjur. Instrumen-instrumen Balaganjur banyak dalam bentuk berpasangan; lanang-wadon atau laki perempuan. Sistem laras menggunakan istilah ngumbang-ngisep; nada yang sama namun dengan frekuensi yang berbeda, yang sedikit lebih rendah disebut ngumbang dan nada yang sedikit lebih tinggi di-sebut ngisep. Teknik bermain kotekan; menggunakan pukulan sang-sih (yang jatuh diantara ketukan) dan pukulan polos (yang jatuh pada ketukan). Semuanya ini mengingatkan adanya makna ke-seimbangan yang tidak selamanya sejajar, tetapi dalam interaksi yang bersifat kompetitif.

Keseimbangan dalam dimensi tiga banyak mempengaruhi para seniman Bali dalam membagi ruang vertikal. Pembagian ruang secara vertikal mempengaruhi cara orang Hindu menggunakan bagian-bagian tubuh mereka. Menurut konsep Tri Angga tubuh manusia dibagi menjadi tiga; kepala sebagai utama angga, badan sebagai madia angga, dan bagian kaki sebagai nista angga. Ketiga konsep ini dipinjam oleh kebanyakan seniman karawitan dalam menciptakan gending-gending Balaganjur. Secara struktural dapat diamati terdiri dari tiga bagian pokok, yaitu kawitan diibaratkan sebagai kepala, pangawak diibaratkan sebagai badan, dan pangecet diibaratkan sebagai kaki. Bagian-bagian ini diporsikan secara seimbang untuk terwujudnya bentuk komposisi yang harmonis.

Umat Hindu sangat mengutamakan adanya keseimbangan didalam kehidupan bermasyarakat, baik secara vertikal maupun secara horisontal. Adanya konsep Tri Hita Karana adalah merupa-kan nilai yang dipegang teguh karena mengandung makna keseimbangan, keselarasan, dan keserasian hubungan antara manusia dengan Tuhannya, manusia dengan lingkungannya dan manusia dengan sesamanya. Secara lebih konkrit pengalaman dari konsep tersebut didalam aktivitas bermain Balaganjur merupakan sarana atau media persembahan yang dapat mempererat hubungan diantara sesamanya, memupuk keselarasan dan keserasian dengan lingkungan, serta memenuhi kebutuhan mereka dalam kegiatan-kegiatan spiritual untuk mendekatkan diri dengan Ida Hyang Widhi Wasa. 


\section{Makna Solidaritas}

Sebagai media berkesenian ternyata Balaganjur dapat mengukuhkan nilai-nilai solidaritas dari masyarakat pendukungnya. Untuk memenuhi kebutuhan masyarakat dan agama maka dibentuklah organisasi-organisasi yang bergerak dibidang seni yang mengelola suatu barungan gamelan yang disebut sekaa. Sekaa merupakan unit organisasi terkecil di masyarakat yang anggota-anggotanya berasal dari sebagian anggota tingkat banjar, tingkat desa atau berasal dari kelompok masyarakat yang lebih luas.

Adanya rasa kebersamaan yang dialami oleh sekaa tersebut, secara implisit tercermin pada tatanan orkestrasi di dalam gamelan itu sendiri. Dalam barungan Balaganjur terdapat berjenis-jenis alat dengan bentuk serta fungsinya masing-masing yang saling ketergantungan. Hubungan yang spesifik ini mengandung makna solidaritas, dan dalam lingkup yang lebih luas menyimpan nilai-nilai kehidupan untuk melahirkan rasa kebersamaan, keterbukaan, kemandirian, kepemimpinan dan rasa pengabdian.

\section{1) Rasa kebersamaan}

Dalam bermain Balaganjur perlu menumbuhkan sikap yang luwes, yang secara tidak langsung dapat mendidik masyarakat untuk melahirkan rasa komunitas yang tinggi. Gending-gending yang dipelajari bersama, kekurangan serta kelebihannya diselesaikan secara musyawarah. Seorang penabuh Balaganjur dituntut ke-trampilannya dan mampu mengadakan koordinasi dengan penabuh yang lain. Lebih-lebih dalam gamelan Bali belum adanya partitur seperti dalam musik Barat. Dalam proses ini diperlukan pemahaman terhadap rasa kebersamaan untuk tercapainya penyajian yang sempurna.

\section{2) Keterbukaan}

Dalam belajar memainkan gamelan Balaganjur para penabuh memiliki sifat keterbukaan untuk saling menerima dan saling memberikan. Belajar gamelan secara imitasi, meniru satu sama lain adalah membuka pikiran para penabuh untuk menghayati fungsi dan tanggung jawabnya yang masingmasing berbeda, tanpa perlu menumbuhkan perasaan superiority dan inperiority.

\section{3) Kemandirian}

Para penabuh yang sudah menguasai gending diharapkan mampu menumbuhkan rasa percaya diri tidak tergantung atau dapat dipengaruhi oleh orang lain. Karena kemampuan seorang penabuh akan berpengaruh besar terhadap penyajian sebuah gending. Penabuh diharapkan mempunyai sikap mandiri yang diatur oleh prinsip-prinsip orkestrasi dan komposisi. 
4) Kepemimpinan

Kepemimpinan dalam bermain Balaganjur, tidak semata-mata didasarkan atas kemampuan individu tetapi atas dasar peranan dan fungsi masing-masing. Seorang pemain "pemegang melodi" bertanggung jawab terhadap jalannya melodi gending, serta seorang pemain "pemberi ornamentasi" bertanggung jawab terhadap permainan ornamentasi gending. Sedangkan dalam penyajian se-buah gending dipimpin oleh kelompok instrumen pemurba irama yaitu seorang pemain kendang yang selalu memperhatikan dan tidak terlepas dengan permainan mat sebagai tanggung jawab pemain tawa-tawa dalam kelompok instrumen "pengatur matra".

\section{5) Rasa Pengabdian}

Terwujudnya gending Balaganjur sebagai sebuah ungkapan karya seni harus dipersembahkan, baik untuk kepentingan upacara keagamaan ataupun untuk kepentingan sosial lainnya. Dengan dedikasi yang tinggi, Balaganjur dipertunjukkan sebagai rasa pengabdian terhadap Tuhan Yang Maha Esa. Para penabuh me-nyerahkan diri secara tulus demi suatu kepercayaan yang mereka yakini. Selain untuk mengekspresikan naluri berkesenian, penyajian Balaganjur oleh para penabuh atau pendukungnya, pada intinya merupakan wujud rasa pengabdian bagi kehidupannya.

\section{Balaganjur dalam Makna Profan}

Perkembangan makna Balaganjur sebagai ekspresi berkesenian dalam konteks keterkaitannya dengan ritual menjadi pertunjukan yang bermakna profan dapat dijelaskan dari pendekatan wujud kebudayaan, yaitu dari sistem budaya, sistem sosial dan sistem fisik. Sebab pada hakekatnya setiap unsur kebudayaan bermula dari ide-ide dari nilai-nilai yang mendorong ke arah prilaku dalam bentuk aktivitas yang akhirnya menghasilkan peralatan atau benda-benda konkret.

Makna profan Balaganjur dari aspek sistem budaya adalah dijadikannya Balaganjur sebagai "media ungkap seni” atau menjadi sumber inspirasi dalam konteks intepretasi estetis maupun akulturasi seni antara tradisi dengan seni modern. Munculnya karya seni dengan media Balaganjur semuanya bermula dari dunia ide para senimannya dengan mempertimbangkan manfaat praktis yang secara positif perlu dipertahankan dan dikembangkan.

Makna profan pertunjukan Balaganjur dari aspek sistem sosial adalah sebagai media penyaluran pengisi waktu dengan berkesenian, berkumpul, dan berorganisasi. Para seniman ketika merintis lahirnya sebuah seni pertunjukan, memiliki wadah berkesenian yang tidak terikat dengan ritual keagamaan. Begitu pula seniman mempunyai ekspresi berkreativitas seni yang lebih memberikan kebebasan untuk berimprovisasi. 
Pembentukan sekaa-sekaa Balaganjur yang kini tersebar di Bali, pada prinsipnya dapat mengangkat potensi seni di masing-masing komunitas. Sebuah sekaa Balaganjur terwujud dari sosio-estetis para seniman tabuh. Sesuai dengan peran dan tugasnya, semua sekaa mendapat pengakuan untuk mengekspresikan bakat seni dan rasa keindahannya yang terungkap lewat Balaganjur.

Makna profan pertunjukan Balaganjur dari aspek sistem fisik adalah leluasanya para seniman dan sekaa-sekaa Balaganjur menjelajahi berbagai kemungkinan konsep artistik, baik dari segi musikalitasnya maupun tata penyajiannya. Balaganjur dari aspek sistem pisik jika ditinjau dari kreativitas ekonomi adalah kebebasan akan tempat, waktu, keadaan dan penyajiannya. Dalam konteks presentasi estetis sebagai tontonan wisatawan, Balaganjur tidak mengklasifikasikan tempat, yang penting arenanya dianggap cukup pementasannyapun dapat berlangsung. Dalam konteks profan pada prinsipnya Balaganjur dapat dipentaskan kapan saja. Tetapi untuk pementasan di ruang terbuka, Balaganjur lebih ideal dipentaskan sebagai musik prosesi dengan pertimbangan estetika dan efek akustika.

\section{a. Makna Estetis}

Agama Hindu merupakan unsur paling dominan sekaligus merupakan roh budaya Bali. Agama Hindu adalah sumber utama dari nilai-nilai yang menjiwai kebudayaan Bali. Setiap hasil kreativitas budaya Bali termasuk kesenian seperti Balaganjur tidak akan bisa lepas dengan ikatan nilai-nilai luhur budaya Bali, terutama nilai-nilai estetika yang bersumber dari agama Hindu.

Estetika berasal dari kata aisthesis dalam bahasa Yunani dapat diartikan sebagai rasa nikmat, indah yang timbul melalui pencerapan panca indra (Djelantik, 2004:5). Estetika dimaknai sebagai keindahan yang dapat merangsang dan mendorong manusia untuk berkreasi dan bersikap dinamis untuk mencapai kepuasan bathin dalam mempertajam intuisinya yang menyangkut rasa keindahan yang membuat kita senang, terkesima, terpesona, bergairah dan bersemangat.

Kebutuhan manusia akan rasa kenikmatan estetis mendorong mereka untuk terus menciptakan objek-objek bernilai estetis. Jika diperhatikan di sekeliling kita terdapat berbagai objek yang dapat menimbulkan rasa lango (menyenangkan). Di jalan-jalan kita melihat benda-benda yang bernuansa estetis seperti patung-patung, tiang-tiang lampu, ukiran-ukiran rumah dan dekorasi-dekorasi lainnya. Akan tetapi benda-benda estetik yang ada di sekitar kita sesungguhnya tidak semua diciptakan oleh seniman atau penciptanya dengan tujuan yang sama sebagai benda kesenian. Ada karyakarya seni yang memang sengaja dibuat untuk dinikmati keindahannya dan tidak sedikit yang semula berupa benda atau barang pakai yang baru kemudian dijadikan benda seni. Oleh Jacques Maquet menamakan tiap-tiap 
objek keindahan menjadi art by distination dan art by metamorphosis (Dibia, op. cit. p. 96).

Seni pada dasarnya tidak dapat dipisahkan kehidupannya dengan masyarakat, terutama masyarakat Bali. Seni dan masyarakat adalah satu. Oleh karena itu nilai estetis adalah sangat kuat dalam kehidupan masyarakat Bali. Kesadaran dan kehidupannya di bidang seni sangat tinggi, dan boleh dikatakan antara seniman dan masyarakat penontonnya terdapat komunikasi yang hidup (Mantra, 1993:32). Keberadaan seni pertunjukan dalam kehidupan masyarakat tidak dapat dilepaskan dari fungsinya sebagai suatu sarana interaksi dan komunikasi dalam masyarakat yang mengandung makna tertentu utamanya bermakna estetis.

Pembicaraan mengenai Balaganjur yang bernilai artistik bertumpu kepada masalah rasa akan selalu mengacu kepada dua sisi yang terkait, yaitu objektivitas dan subjektivitas. Sisi yang pertama menyangkut realita atau kenyataan dari bentuk Balaganjur, sedangkan sisi yang kedua menyangkut kesan yang ditimbulkan oleh Balaganjur tersebut. Oleh sebab itu, hasil penilaian estetis yang optimal dapat dicapai dengan memadukan kedua sisi objektif dan subjektif.

Penilaian terhadap kualitas Balaganjur secara estetis, juga sering kali ditentukan oleh etika (norma baik buruk) yang berlaku di lingkungan masyarakat budaya setempat. Kualitas keindahan Balaganjur sering kali kehilangan makna estetisnya jika ternyata didalamnya terdapat unsur-unsur yang bertentangan dengan etika yang ada dalam masyarakat. Oleh karena itu di lingkungan budaya tertentu kenikmatan keindahan juga memberikan kesenangan sesuai dengan norma baik-buruk yang berlaku.

Estetika Hindu pada intinya merupakan cara pandang mengenai rasa keindahan yang diikat oleh nilai-nilai agama Hindu yang didasarkan atas ajaran-ajaran kitab suci Weda. Ada beberapa konsep yang menjadi landasan penting dalam estetika Hindu. Konsep-konsep yang dimaksud antara lain konsep kesucian, konsep kebenaran dan konsep keseimbangan (Dibia, op. cit. p. 96).

Kesucian pada intinya menyangkut nilai-nilai ketuhanan yang juga mencakup yadnya dan taksu. Umat Hindu seperti yang terlihat di Bali, memiliki pandangan estetik yang diikat oleh nilai-nilai spiritual ketuhanan sesuai dengan ajaran agama Hindu. Seperti telah banyak dikemukakan oleh para pakar agama Hindu, bahwa Tuhan itu adalah maha-indah dan sumber dari segala keindahan. Atas ke-percayaan ini manusia Hindu percaya bahwa segala sesuatu yang bernilai artistik adalah ciptaan Tuhan.

\section{b. Makna Kreativitas}

Berbicara tentang perwujudan karya seni, belumlah sempurna sebelum menyebut dua macam perbuatan dan perilaku kesenian yang berbeda secara mendasar, yakni kreativitas; perilaku kesenian yang 
menghasilkan kreasi baru, dan produktifitas; perilaku kesenian yang menghasilkan produksi baru merupakan ulangan dari apa yang telah terwujud, walau sedikit percobaan atau variasi di dalam pola yang telah ada (Djelantik, op. cit. p. 67).

Kebebasan berkreasi tidak berhenti pada satu titik atau era tertentu. Sepanjang proses berkesenian itu terus bergulir, selama itu kreasi-kreasi baru akan terus ada, artinya pada suatu era suatu produk seni adalah sebuah kreasi baru. Namun ketika kreasi baru itu sudah biasa dan tidak baru lagi atau sudah menjadi pola tertentu, maka muncullah kreasi-kreasi yang lebih baru lagi yang pada era-era berikutnya kembali menjadi tidak baru, demikian seterusnya (Ibid., p. 68).

Kayam (1981:39) antara lain mengemukakan bahwa kesenian tidak pernah lepas dari akar kulturnya yakni masyarakat. Masyarakat sebagai pendukung kesenian dan kebudayaannya tidak pernah berhenti berkreasi. Kesenian adalah ungkapan kreativitas dari kebudayaan itu sendiri. Masyarakat sebagai menyangga kebudayaan, demikian pula kesenian dapat memberikan peluang untuk bergerak, memelihara dan mengembangkan. Sedangkan kreativitas masyarakat berasal dari manusia-manusia yang mendukungnya.

Berpijak dari konsep Kayam tersebut, maka Balaganjur merupakan salah satu ungkapan kreativitas masyarakat dalam bidang seni pertunjukan, memiliki unsur-unsur yang bermakna dalam kehidupan bermasyarakat. Dorongan ke arah kreativitas dan pengalaman-pengalaman estetis dihidupi oleh semangat jiwa yang mendorong untuk tampil ke depan dan mengorbit (Sumandiyo, 2003:6). Sehubungan dengan dorongan kreatif serta kebutuhan indra yang mendasar, Balaganjur kaya akan warna nada dan ritme.

Lomba Balaganjur dan difungsikannya Balaganjur sebagai musik iringan tari merupakan babakan baru dari moment kreatif gamelan Bali. Sehingga penataan artistik dalam Balaganjur menempati proporsi yang lebih dominan, Balaganjur sudah menjadi bentuk seni pertunjukkan tersendiri; para pemain sebagai penabuh dan juga sebagai penari. Hal ini merupakan bentuk kreativitas baru dalam menyemarakkan kehidupan dan perkembangan dunia kesenian, tentunya tidak terlepas dari peranan seniman didalam melahirkan nuansa baru dalam seni pertunjukan di Bali.

Seniman selalu berusaha memperbaharui tingkat perkembangan terakhir dari sebuah perkembangan. Tidak jarang garapan Balaganjur memiliki unsur kerumitan yang sangat tinggi dengan menampilkan kompleksitas garap melalui penonjolan pada pengolahan dinamika, ritme, melodi dan harmoni. Secara konsepsual telah menunjukkan adanya ungkapan kreativitas selera kekinian, terutama dalam hal penyajian gendinggending Balaganjur yang muncul belakangan ini.

Demikian pula upaya-upaya untuk menghasilkan sebuah ungkapan baru tidak saja mengolah materi yang telah ada melainkan menggali, 
menambahkan atau juga mereformasi bentuk-bentuk yang telah ada, sehingga memberi nuansa dan kesan yang baru pula. Memadukan unsurunsur lama dan baru juga merupakan upaya kreatif seorang seniman, dalam upaya menghadapi pengaruh kultural dari luar dengan mencari bentuk dan model untuk menyesuaikannya.

Kusumawardani (2003:339), menyatakan berbagai bentuk seni timbul karena kemampuan manusia untuk menggali pandangan-pandangan yang tajam dari pengalaman hidup, karena keinginan untuk memberikan bentuk luar dari tanggapan serta imajinasi yang unik. Seni berkaitan erat dengan kreativitas, tentunya identik dengan kegiatan inovasi untuk menemukan gagasan baru, ide-ide baru yang cemerlang, fungsional dan komunikatif.

\section{c. Makna Ekonomi}

Ketika menjadi seni pertunjukan sekuler, Balaganjur telah mengalami perkembangan makna secara sistem budaya, sistem sosial dan sistem pisik. Perkembangan Balaganjur dari makna relegius dalam konteks ritual kepada makna ekonomi dapat ditinjau dari kreativitas estetis dan aktivitas sebagai seni wisata.

Balaganjur bermakna ekonomi dapat ditinjau dari aspek sistem budaya pada aktivitas dan kreativitas Balaganjur dalam perkembangannya menjadi seni pertunjukan turistik, penyajian Balaganjur dapat ditonton dan dibayar oleh para wisatawan. Munculnya Balaganjur sebagai tontonan turis di Bali merupakan stimulasi dari potensi pasar wisata dan kesadaran ekonomi para seniman Balaganjur.

Sebagaimana yang diramalkan oleh Covarrubias, kini terbukti bahwa perkembangan pariwisata telah membawa energi dobrak yang sangat dahsyat, sehingga menyebabkan perubahan-perubahan yang sangat struktural bagi masyarakat dan kebudayaan Bali (Bagus, 1977:92). Industri pariwisata adalah cermin teknologi modern. Ia digarap, dikelola dan digerakkan menurut prinsip dan nilai-nilai modern, nilai-nilai yang terutama berlaku dalam tatanan masyarakat yang sudah bergeser dari statusnya yang "utuh" dan "tertutup". Karena industri ini percaya kepada kompetisi, kepada prestasi individu, kepada efisiensi organisasi, kepada pengejaran dan perluasan keuntungan, kepada pengembangan yang terus menerus.

Pariwisata dalam arus modernisasi mengarahkan per-kembangan kebudayaan ke suatu arah modernitas. Pariwisata pada suatu sisi memberikan dampak positif, karena telah memberikan kontribusi yang mampu meningkatkan kesejahteraan masyarakat Bali yang tidak kecil jumlahnya. Demikian pula pada kehidupan berkesenian seperti Balaganjur selalu memberikan peluang untuk memunculkan kreativitas yang baru untuk menghibur wisatawan, sekaligus sebagai salah satu daya tarik pariwisata.

Barker (2004:115), menjelaskan globalisasi bukan hanya menyangkut persoalan ekonomi saja, melainkan juga telah terkait dengan isu budaya. 
Kendatipun nilai makna yang sudah melekat pada suatu tempat tetap mempunyai arti, bagi yang berkiprah di bidang budaya merasa semakin terjerat dalam jaringan yang meluas jauh keluar dari fisik budaya. Dalam hal ini yang digambarkan budaya bukanlah suatu bagian dari negara atau budaya dunia yang satu, namun di sini cukup jelas dapat mengidentifikasikan proses global, integrasi dan disintegrasi budaya, yang terlepas dari hubungan antar negara. Globalisasi yang mengalami percepatan pada era modernitas akhirnya menjadikan metafora perjalanan begitu relevan karena semua yang lokal kini mampu dipengaruhi.

Makna ekonomi seni pertunjukan Balaganjur dari aspek sistem sosial adalah munculnya Balaganjur sebagai komuditas pariwisata. Sebagian besar dari motivasi sekaa-sekaa Balaganjur adalah didasari oleh suatu kesepakatan sosio-ekonomis, dimana orientasi pasarnya adalah para wisatawan yang datang ke Bali. Sangat jarang ada pementasan Balaganjur yang mencari keuntungan finansial dari masyarakat lokal Bali.

\section{SIMPULAN}

Balaganjur adalah sebuah bentuk komunikasi musik yang dapat membangkitkan respon-respon emosional dan menggugah perasaan, tetapi tidak dapat memberi pengertian nyata atau gagasan berpikir seperti yang nampak dalam kata benda, kata kerja, dan kata sifat. Balaganjur adalah bahasa abstrak yang artinya tergantung dari hubungan antara pencipta dan pendengarnya. Balaganjur memang dapat mempengaruhi pendengarnya dan hanya berhubungan dengan pendengar yang akrab dengan latar belakang sosial dan sejarahnya.

Memperhatikan Balaganjur di tengah-tengah masyarakat dewasa ini, ternyata Balaganjur sangat relevan dengan sistem kemasyarakatan yang serba unik. Balaganjur menjajikan berjuta-juta harapan yang harus dilestarikan dan dikembangkan dimasa yang akan datang dalam menunjang kehidupan beragama. Keberadaan Balaganjur merupakan proses dialektis budaya, yakni bagaimana suatu komunitas memahami nilai-nilai estetisnya dan bagaimana para pelakunya memanfaatkan secara konstruktif nilai-nilai itu untuk kemajuan adab kemanusiaan dan kebudayaannya.

Nilai-nilai tradisi yang memberi stimulasi kehadiran Balaganjur dalam khasanah kesenian Bali, merupakan mutiara-mutiara yang telah diwariskan oleh generasi terdahulu mampu memberikan kontribusi pada hasrat-hasrat estetis dalam sebuah kerja kreatif kepada pionir-pionir kebudayaan masyarakat kekinian. Keberagaman nilai-nilai estetis tradisi yang belum semuanya mendapat perhatian itu menjadi tambang emas bagi pencarian puncak-puncak kerja kreatif untuk keluhuran dunia kesenian dan martabat sukmawi dan duniawi manusia. 
Balaganjur semestinya diberikan harkat yang pantas. Kepantasan itu tidak hanya mendapatkan apresiasi sebagai sebuah nilai estetis semata, tetapi juga karya cipta seni yang memberikan harkat yang pantas kepada para pelakunya dan masyarakat pemilik kesenian itu. Oleh karena itu, para pengayom dari berbagai pihak yang peduli dengan Balaganjur hendaknya ikut mengkondisikan atmosfir yang positif dan konstruktif. Respek terhadap makna yang dimiliki dan nilai estetis yang dipersembahkan Balaganjur merupakan refleksi dari pengakuan dan kecintaan akan cinta kasih, persaudaraan dan perdamaian.

\section{DAFTAR RUJUKAN}

Astika, Ketut Sudhana. 1994. "Sekaa Dalam Kehidupan Masyarakat Bali", dalam Dinamika Masyarakat dan Kebudayaan Bali. Denpasar: Bali Post.

Bagus, I Gusti Ngurah, (ed). 1977. Masalah Budaya dan Pariwisata dalam Pembangunan. Denpasar : Universitas Udayana.

Bandem, I Made. 1983. Peranan Seniman Dalam Masyarakat. Proyek Penelitian Pengkajian dan Pembinaan Nilai-nilai Budaya: Direktorat Pendidikan dan Kebudayaan. Direktorat Jenderal Kebudayaan. Direktorat Sejarah dan Nilai Tradisional. 1991. "Peranan Kesenian Dalam Menunjang Pembangunan Daerah Bali". Sekolah Tinggi Seni Indonesia Denpasar.

Barker, Chris. 2004. Cultural Studies, Teori dan Praktek. Yogyakarta: Kreasi Wacana.

Dibia, I Wayan. 2003. "Nilai-nilai Estetika Hindu dalam Kesenian Bali", dalam Estetika Hindu dan Pembangunan Bali. Denpasar : Program Magister Ilmu Agama dan Kebudayaan Universitas Hindu Indonesia Bekerja sama dengan Penerbit Widya Dharma.

Djelantik, A.A. Made. 1994. 2004. Estetika Sebuah Pengantar. Bandung: Masyarakat Seni Pertunjukan Indonesia.

Sumandiyo, Hadi. 2000. Seni dalam Ritual Agama. Yogyakarta: Yayasan Untuk Indonesia.

Kayam, Umar. 1981. Seni, Tradisi, Masyarakat. Jakarta: Sinar Harapan.

Kusumawardani. 2003. "Kombinasi Berpikir Lateral Dan Berpikir Vertikal dalam Berpikir Kreativitas Tari". Dalam Jurnal Pengetahuan dan Penciptaan Seni. Yogyakarta: PB ISI.

Mantra, Ida Bagus. 1993. Sosial Bali Masalah dan Modernisasi. Denpasar: PT Upada Sastra.

Suartaya, Kadek. 2001. "Transformasi Cak Dari Ritual Magis Ke Presentasi Estetis” (tesis). Program Pasca Sarjana Universitas Udayana Denpasar.

Sugiartha, I Gede Arya. 1996. "Bleganjur Sebuah Musik Prosesi Bali Continuitas dan Perkembangannya" (Laporan Penelitian). Proyek 
Operasi dan Perawatan Fasilitas STSI Denpasar, Dip. No. 298/XXIII/ 3/-/ 1996 tanggal 30 Maret 1996: Sekolah Tinggi Seni Indonesia Denpasar. 